Relations industrielles

Industrial Relations

\title{
Arthur B. Shostak, Robust Unionism. Innovations in the Labor Movement
}

\section{Joseph B. Rose}

Volume 47, numéro 1, 1992

URI : https://id.erudit.org/iderudit/050749ar

DOI : https://doi.org/10.7202/050749ar

Aller au sommaire du numéro

Éditeur(s)

Département des relations industrielles de l'Université Laval

ISSN

0034-379X (imprimé)

1703-8138 (numérique)

Découvrir la revue

Citer ce compte rendu

Rose, J. B. (1992). Compte rendu de [Arthur B. Shostak, Robust Unionism. Innovations in the Labor Movement]. Relations industrielles / Industrial Relations, 47(1), 157-158. https://doi.org/10.7202/050749ar

Tous droits réservés @ C Département des relations industrielles de l'Université Laval, 1992
Ce document est protégé par la loi sur le droit d'auteur. L'utilisation des services d'Érudit (y compris la reproduction) est assujettie à sa politique d'utilisation que vous pouvez consulter en ligne.

https://apropos.erudit.org/fr/usagers/politique-dutilisation/ 
auteurs réunis dans cet ouvrage proposent une critique relativement cohérente de la théorie dunlopienne des relations industrielles. Il se dégage de l'ensemble de ces contributions l'idée maîtresse que l'évolution des régles professionnelles ne dépend pas principalement des variations affectant les structures technologiques, économiques ou politiques mais résulte d'interactions complexes entre l'environnement et les acteurs du système de relations industrielles. La qualité indéniable de la plupart de ces contributions atteste également que l'absence de programmes d'enseignement universitaires spécialisés dans le domaine des relations industrielles en France n'a pas empêché le développement de nombreux centres de recherche voués à l'avancement de cette discipline. C'est le cas notamment du Laboratoire de sociologie du travail et des relations professionnelles (LSTRP), du Conservatoire national des arts et métiers de Paris animé par Jean-Daniel Reynaud, du Laboratoire d'économie et de sociologie du travail (LEST) d'Aix-en-Provence fondé par François Sellier et du Groupe lyonnais de sociologie industrielle (GLYSI) dirigé par Philippe Bernoux, d'où proviennent quinze des vingt-sept articles publiés dans cet ouvrage.

Feynald Bouroue

Université du Québec à Hull

Robust Unionlsm. Innovations in the Labor Movement, by Arthur B. Shostak, Ithaca, N.Y., ILR Press, 1991, 368 p., ISBN 0-87546-169-7 (alk paper) and ISBN 0-87546-170-0 (pbk: alk paper)

Arthur Stostak's new book swims against the tide of the contemporary literature on U.S. unionism. It does not dwell on the decline of American unions or the pessimistic predictions about the future of the labour movement. Rather, he probes below the battered exterior and discovers "robust" unionism and a basis for optimism. The result is an interesting and alternative perspective.

The book is organized into six broadly-defined topics. Part I deals with workplace issues, including substantive matters such as safety and health promotion at work (e.g., employee assistance plans and drug testing) and the development of workplace strategies. Part II is concerned with union organizing (e.g., new approaches and strategies for organizing the service sector, professionals and women) and union reorganizing (i.e., keeping members engaged in their union). In Parts III and IV, the focus is on the role of unions in community service (e.g., achieving low-cost medical services for victims of plant shutdowns and the effective use of retired unionists in community projects), public relations and politics. Part $V$ explores new forms of worker involvement in business, including ESOP's, worker cooperatives, and the strategic use of pension funds, as well as union efforts to forge new and more effective alliances with community groups. In Part VI, Shostak considers the utility of strategic planning and union mergers for modernizing the labour movement. There also is an extensive directory at the back of the book which lists organizations which offer labour-related resources. 
A standard format is adopted for each part of the book. The sections begin with an overview of the topic followed by short essays and case studies. Anticipating that some readers will not be convinced of the usefulness or significance of robust unionism, several chapters contain sections entitled "A Word From the Skeptics", where Shostak debates "invisible" critics. The writing style is concise, relaxed and free of academic jargon. It is evident the author strives to portray the breadth of robust unionism rather that its depth. By robust unionism, the author is referring to numerous projects, experiments and innovations undertaken by unions (usually local unions). These undertakings reflect (1) the social consciousness and scope of union activities (i.e., the notion that unions have pushed beyond the frontiers of "pure and simple business unionism") and (2) the ability of unions to achieve major gains with minimal leverage. The book is aimed at attracting a broad readership rather than appealing to the academic community. This is not meant to suggest the book is of no interest to industrial relations scholars. On its own terms, the book is quite informative and engaging. The author has amassed a large collection of union projects worthy of illustration and raised important questions about the prospects for reviving the American labour movement.

The book does a number of things very well. First, it clearly demonstrates the diversity of unionism. Second, the book provides the philosophical and economic arguments for and against various union innovations (e.g., ESOPs). One criticism is the book merely scratches the surface on many of these issues and the emphasis generally tends to be on the pro arguments rather than the con arguments. Third, some of the cases are outstanding, including those dealing with the reorganization of air traffic controllers, the organization of support staff at Harvard University, the United Airlines' pilot strike and the strategic use of union pension funds. Given its topical nature and its emphasis on case studies, this book could have been entitled "What Else Do Union Do?"

For this reader it was a refreshing change to read about the creativity and dynamism of the American labour movement. It is not that we doubted its existence, but rather that we hear so little about it. Unfortunately, it is difficult to determine what these examples of robust unionism signify. Some may believe there is a basis for a resurgence in U.S. unionism. Others, and I suspect the majority, will point to the contradictions between robust unionism and the traditional opposition to change within the labour movement. Even Shostak acknowledges that future problems cannot be solved with yesterday's solutions.

Joseph B. Rose

McMaster University

The Permanent Revolution? Conservative Law and the Trade Unions, by John Mcllroy, Nottingham, Spokesman (for the Society of Industrial Tutors), 1991, 253 p., ISBN 0-85124-528-5

Margaret Thatcher became leader of the British Conservative Party in the mid-1970s at a time of intense debate about the direction of economic policy. The post-war consensus within British politics which had existed around government 